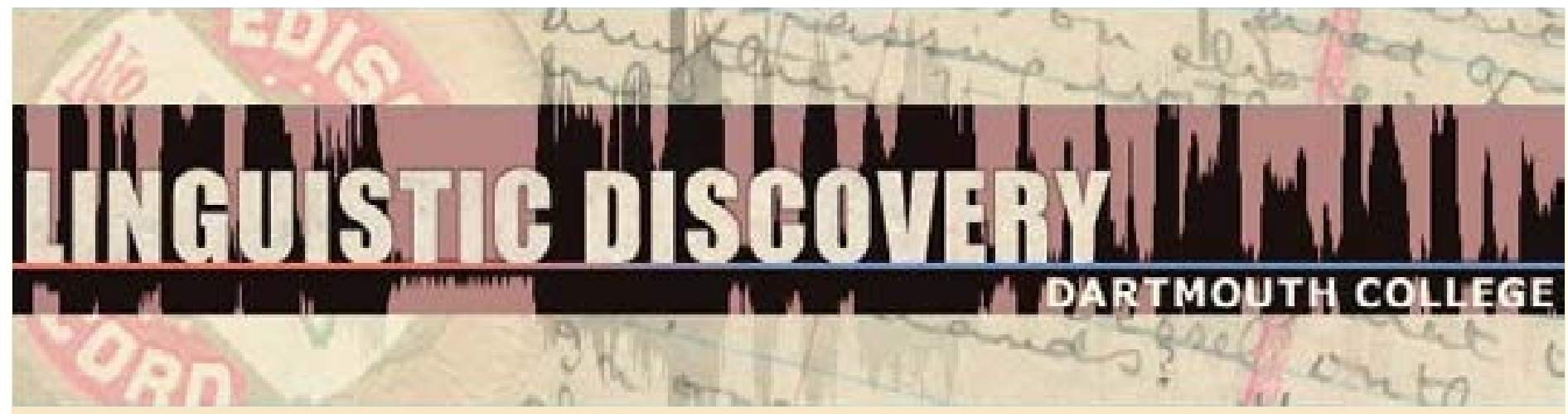

\begin{tabular}{|l|}
\hline Volume 8 \\
Issue 1 \\
2010 \\
\hline
\end{tabular}

\title{
A Diachronic Dimension in Maps of Case Functions
}

Heiko Narrog

Tohoku University

doi: 10.1349/PS1.1537-0852.A.352

url: http://journals.dartmouth.edu/cgi-bin/WebObjects/ Journals.woa/1/xmlpage/1/article/352

\section{Linguistic Discovery}

Published by the Dartmouth College Library Copyright to this article is held by the authors. ISSN 1537-0852 linguistic-discovery.dartmouth.edu 


\section{A Diachronic Dimension in Maps of Case Functions \\ Heiko Narrog \\ Tohoku University}

One of the advantages of classical semantic maps with distinct connections between individual meanings (or functions) is that they are well suited for the inclusion of diachronic information. This paper intends to demonstrate how information on the directionality of meaning extension can be integrated into such maps. For this purpose, the diachronic dimension of three areas of case function, namely Companion-Instrument, Source-Agent, and Goal-Recipient, was investigated. As a result, it was found that in the case of most connections between meanings/functions in these areas, a clear directionality can be hypothesized, and relatively robust diachronic semantic maps can be constructed.

\section{Why Diachronic Information Is Important for Semantic Maps}

Semantic maps are a relatively new approach to the representation of semantic and functional relationships. They are usually traced back not much further than to Anderson $(1982,1986)$. However, the last couple of years have seen an exponential rise of interest in, and increase in use of this methodology, including such important contributions as Haspelmath (1997, 2003), van der Auwera \& Plungian (1998), Croft (2001), and Malchukov (2004). In classifying the specimen of maps as they are used in the field of grammar, I suggest that basically two types of representation can be distinguished. The first type of representation posits distinct "connections" between meanings. I will call this type a "classical" map, because the first maps by Anderson $(1982,1986)$ were drawn in this fashion. The second type simply shows spatial adjacency between meanings or functions, sometimes plotted on the basis of statistical information. Croft's maps (e.g. Croft 2001, Croft \& Poole 2008) can be thought of as representative of this approach.

Concerning the "classical" maps, the factors that have made them attractive for researchers include the following: (1) they can graphically represent similarity relationships between meanings or functions; (2) they can graphically represent possible versus impossible or, empirically speaking, attested vs. non-attested connections between meanings or functions (i.e. polysemous extensions); (3) they may contain implicational universals; (4) they can graphically represent information about the directionality in the connections between meanings - the main topic of this paper.

Especially factors (2) to (4) can be seen as advantages of a classical map since these are points that can be represented only with much greater difficulty, if at all, on purely spatially arranged maps. On the other hand, spatially arranged, especially statistically plotted maps are potentially more accurate in representing similarity relationships. Beyond that, the potential advantages that classical maps offer also come at a price. The meaningfulness of classical maps basically relies on point (2). If on a map every meaning/function is related to every other meaning/function, and no connection can be excluded, the map becomes almost meaningless, or "vacuous" (cf. Haspelmath 2003:218). Figure 1 is an example of such a map. 


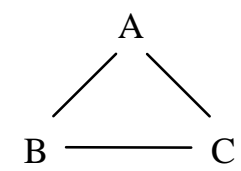

Figure 1: A vacuous semantic map, or, how semantic maps ought not to look

In the case where such no relationship between meanings or functions is excluded, only a spatially arranged map containing statistical information is still meaningful, except perhaps for the fact that showing that all meanings/functions in an area are related still has some meaning.

Now, the problem is that many semantic maps, if empirical data are taken seriously and minority patterns are not conveniently excluded, end up looking like Figure 1 or at least having areas like Figure 1. Another example is provided by Figure 2 which is based on a data set that was used for this paper and will show up again later in Section 7 (we will leave the meanings/functions unnamed for now):

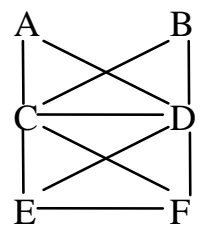

Figure 2: How a semantic map can actually look

This map still makes a number of interesting predictions, such as, for example that meaning/function A cannot be directly connected with meaning/function F, but in the area of $\mathrm{C}$, D, E, and F, for example, no possibility can be excluded, and therefore the map's informational value is low. A statistically plotted map of this area would instead precisely show the similarity of the meanings/functions in this area.

However, the unique value of the classical maps, which presuppose the existence not only of similarities but also of connections between meanings or functions, is still present if factor (4) comes into play, namely the addition of a dynamic dimension of meaning extension. Figure 3 adds such a (in this case fictitious) diachronic directionality to the meanings/functions depicted in Figure 1.

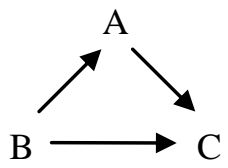

Figure 3: How directionality information can make an otherwise vacuous map meaningful

Figure 3 presents the hypotheses that meaning $\mathrm{C}$ in is an extension of either meaning $\mathrm{A}$ or meaning B, but the opposite direction is not allowed. Furthermore, meaning A can be derived from meaning B but not vice versa. That is, although the bare connections represented in Figure 1 were of little informational value, the addition of a diachronic dimension suddenly turns this map into an interesting map. It is furthermore a map that represents information which cannot (or 
only with great difficulty) be represented on statistically plotted maps.

Thus, the point which has been made here is that a diachronic dimension in classical maps gives this type of map a unique value which is hard to achieve with other means of representation. The endeavor to add a diachronic dimension to semantic maps, with all its difficulty, is therefore profitable if not highly desirable. This endeavor, of course, depends on the actual historical existence of directionalities. Here grammaticalization theory comes into play; grammaticalization theory has claimed (for the most part successfully, I believe) that most semantic change in the area of grammar is unidirectional (cf. Haspelmath 1999; Heine 2003; Hopper \& Traugott 2003, ch. 5; Traugott \& Dasher 2002). There is good reason to hope that unidirectional relationships of meaning extension as represented in Figure 3 actually exist in many areas of grammatical semantics.

The present paper explores the existence of such unidirectional relationships in the area of case functions. The following section gives a brief overview of the larger project of constructing a semantic map of case functions, the present paper being a part of this project. Section 3 introduces data and methods. Sections 5 to 7 deal with the Instrument-Companion, Source-Agentive, and Recipient-Goal area. Section 8 discusses directionalities found in this paper in their relationship to broader directionalities of grammaticalization and semantic change. A short summary follows in section 9.

\section{The Project}

This paper presents research that should ideally lead to a cross-linguistically valid semantic map of case functions. This map is to be based on an inventory of case marker polysemy in a sample of 200 languages (which is currently based on Ruhlen 1987 and Rijkhoff \& Bakker 1998). Particular semantic functions, for example the Instrumental and the Comitative, are taken as starting points. The ultimate goal would be to automatically calculate a semantic map with distinct connections between meanings from polysemy data. However, for reasons explained by Croft \& Poole (2008) among others, this is mathematically impossible at present. The author therefore attempted to find a replicable procedure that would somehow come close to the automatic calculation of a map. The result has been described in a previous study (Narrog \& Ito 2007). Proceeding from a synchronic perspective, relationships between meanings are posited (1) on the basis of simple mathematics, namely the calculation of the "dependency" of one meaning on others, and (2) on singular co-occurrences of one meaning with a specific other meaning. Concretely, in terms of (1), the requirement is that each of the meanings must appear in at least 10 morphemes in the database. Then, if the occurrence of one meaning depends on another meaning by more than $90 \%$ (0.9), the existence of a connection between those two meanings is hypothesized. Extending the calculation to relations between three meanings, a dependency of more than $81 \%(0.9 * 0.9)$ is required, with the three meanings occurring simultaneously in at least 5 morphemes. Concerning (2), it is assumed that if a morpheme $\mathrm{M}$ has only the meanings $\mathrm{A}$ and $\mathrm{B}$, and this situation occurs in at least three different languages, there is a direct connection between these two meanings.

Based on these procedures, the map in Figure 4 was hypothesized (cf. Narrog \& Ito 2007, Narrog 2008, Malchukov \& Narrog 2008). Solid lines indicate the result of calculation for two meanings (1), square dotted lines the result of calculation for three meanings, round dotted lines the result of the assumption (2), and long-dashed lines the result of the second assumption under less strict conditions, namely in only two languages. 


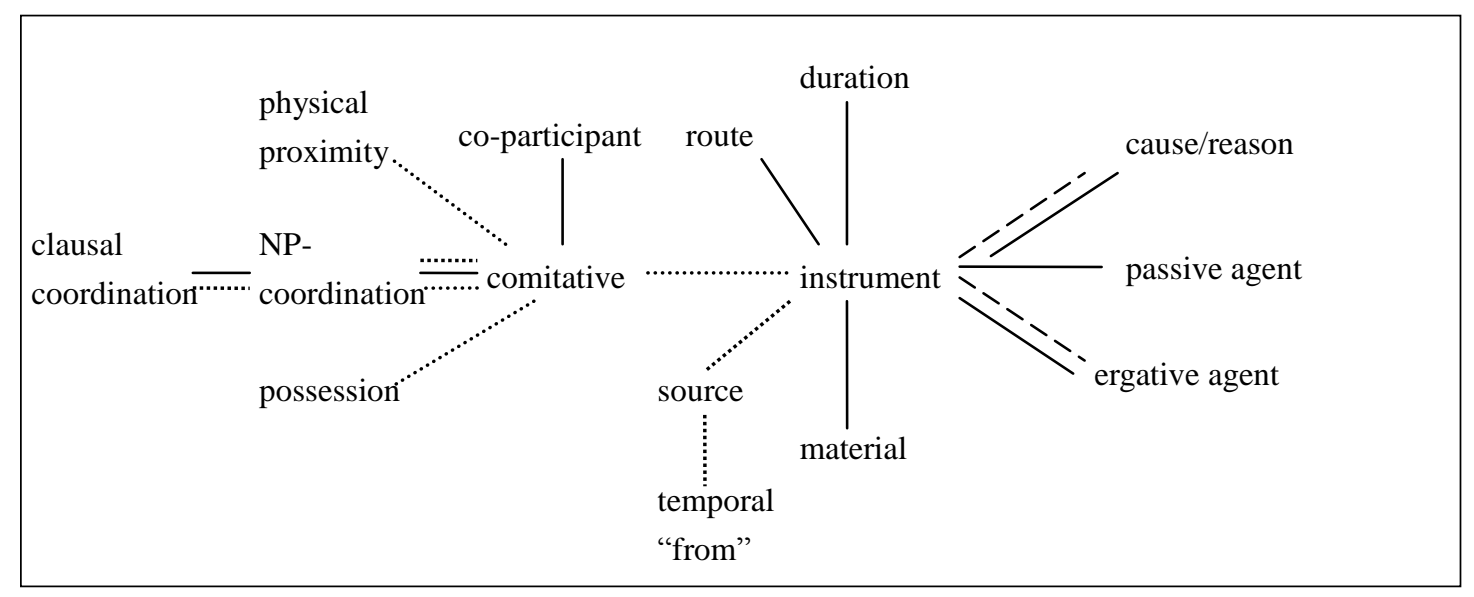

Figure 4: Map of the Comitative-Instrumental domain (cf. Narrog \& Ito 2007)

\section{Data and Procedures}

We now return to the goal of the present paper, which is to add a diachronic dimension to the semantic map of the Comitative-Instrumental domain in Figure 4 and the data that it represents. Furthermore, the map should be extended beyond the Comitative-Instrumental domain, namely into the Source-Agentive domain and the Recipient-Goal domain. The following premises were adopted, and the following steps were taken to proceed towards this goal.

1) Although the topic here is "case", which in some theories is limited to core grammatical cases and/or dependent morphology (noun inflection), we have included semantically highly specified functions of noun phrases and have not limited ourselves to morphological case but have also included morphologically independent material such as adpositions (in many languages, the distinction between case inflection and adposition depends on the theoretical approach anyway). Inflections and adpositions are referred to commonly as "markers" in this paper.

2) Very basically, a stance was taken which positively acknowledges polyfunctionality (polysemy), as opposed to a monosemy stance.

3) With respect to the relationship between synchronic polyfunctionality and diachronic meaning extension, in accordance with the grammaticalization literature (e.g. Heine 2003:579; Hopper \& Traugott 2003:125), it was assumed that a morpheme usually acquires a new function/meaning while retaining its old function/meaning; i.e. $\mathrm{A}>\mathrm{AB}(>\mathrm{B})$ (A and $\mathrm{B}$ standing for a function/ meaning), and only in rare cases directly $\mathrm{A}>\mathrm{B}$.

4) Although the value of a semantic map profits from the number of unidirectional relationships depicted in the map, such hypotheses which are conflicting or suggest bidirectionality were given specific attention because the resolution of conflicting or contradictory hypotheses is particularly apt to advance knowledge in this area.

5) Related literature was skimmed for hypotheses on meaning extension in the case domain. 
Specifically, general literature on case and on grammaticalization was consulted in order to look for cross-linguistic tendencies or directionalities, while individual grammars as a rule were not included in the investigation.

6) Directionalities posited on the basis of historical evidence, if available at all, were given precedence over directionalities which were solely posited on the basis of internal reconstruction.

As a result of the literature review, 135 hypotheses were found, namely, 31 in the Comitative-Instrumental domain, 38 in the Source-Agentive domain, 48 in the Dative-Allative domain, and 19 elsewhere. 25 of these turned out to be problematic, that is, either they claimed the reverse of one another, or they contradicted general the directionality of language change as posited, for example, in Heine et al. (1991).

The literature review revealed that a large number of hypotheses are based on internal reconstruction or the intuition of the researcher, and historical evidence is scarce. It should be noted that even in languages which have a relatively well-documented history, as for example English, it is not uncommon that the development of polyfunctionality may precede historical documentation, or the historically documented situation is unclear. Relevant authors and works that turned out to be relatively strongly historically oriented include Blake (2001, 2004), and Hopper \& Traugott (2003). Heine and research associates (Heine et al. 1991, Heine \& Kuteva 2002), Stolz and research associates (Stolz 1994, 2001; Stolz, Stroh \& Urdze 2006), and Luraghi (2001a, 2003) present mixed evidence, while Palancar (2002), Yamaguchi (2004), for example, are mainly tuned towards internal reconstruction. Furthermore, it is possible to distinguish between two basic theoretical stances with respect to meaning extension. First, there are cognitively-oriented scholars who basically take a localist stance (that is, local functions are thought to be the foundation for all, or at least most, other functions). Examples are Croft (1991), Heine and associates (Heine et al. 1991 and others), and Luraghi (2001a, 2003 and others). Some scholars implicitly or explicitly do not take this stance (e. g. Lehmann 2002, Palancar 2001, 2002). Note that a different theoretical stance can influence the outcome of internal reconstruction.

\section{Terminology}

The goal of this project is to build semantic maps of case functions. In the area of "case", however, labels of at least three levels are commonly encountered, namely semantic functions, morphological case, and grammatical relations. For example, the same marker (case ending or adposition) may mark a recipient on the level of semantic function, a dative on the level of morphological case, and an indirect object on the level of grammatical relations. It has been common for research in the area of case functions not to make strict distinctions between different levels of description. For example, Givón (2001:107) uses the label "dative" parallel to "agent", "patient" and "instrument", and Rice \& Kabata (2007:490) use "allative" parallel with "recipient" or "purpose". Furthermore, the very same marker might be labeled as "recipient" in one description and "dative" in another description, or as a "dative" marker in one description and an "indirect object" marker in a different description without there being a substantial difference. In the light of the large number of languages included in this research, in most cases solely on the basis of published descriptions, it is impossible to obtain a data basis with equivalent labels. 
In trying to be both practical and consistent, we have dealt with this problem as follows. Grammatical relations markers are with few exceptions excluded from the study because the distance of descriptive level between grammatical relations on the one hand and semantic functions on the other hand is too wide. For the morphological case labels, on the other hand, we assume that they minimally contain the semantic functions listed in Table 1.

\begin{tabular}{|l|l|}
\hline case label & minimally assumed semantic function \\
\hline nominative, ergative & agent \\
\hline genitive & possessor \\
\hline dative & recipient \\
\hline accusative & patient \\
\hline ablative & source \\
\hline allative & goal \\
\hline instrumental & instrument \\
\hline comitative & companion \\
\hline locative & location \\
\hline
\end{tabular}

Table 1: Minimally assumed functions of case labels

From here on we shall work with the semantic function labels for constructing the maps. Taking this procedure, although it may not be theoretically desirable, is unavoidable practically because languages rarely have markers that are monofunctional, and few descriptive grammars give an exhaustive list of the semantic functions that a specific case has. Datives usually also have other functions, such as experiencer or beneficiary, or may be used purely syntactically for a default third argument. Instrumentals often denote material and manner, etc. We assume that they have at least a "recipient" function and an "instrument" function, unless other functions are specifically named, and unless there is evidence to the contrary. These semantic functions, with which we construct our maps, are henceforth written with capital letters.

The following sections, divided by semantic domains, present the actual results of the investigation.

\section{The Instrument-Companion Domain}

\subsection{Uncontroversial directionalities}

For a majority of the relations between meanings/function in Figure 4, a directionality of meaning extension in just one direction has been posited in the literature. These directionalities are listed in Table 2.

Independent of whether the directionalities posited in Table 2 are presumably based on actual historic evidence or "only" on internal reconstruction, we do not question the assumptions behind them here unless a conflict arises with hypotheses that posit a different directionality. These are discussed in a little more detail in the following section (5.2). 


\begin{tabular}{|c|c|c|c|}
\hline Source & target & $\begin{array}{l}\text { literature supporting this } \\
\text { directionality }\end{array}$ & $\begin{array}{l}\text { language examples } \\
\text { cited }\end{array}$ \\
\hline Source & Instrument & $\begin{array}{l}\text { Palancar 2002:181, 234; Luraghi } \\
\text { 2003:322; Creissels (2008) }\end{array}$ & $\begin{array}{l}\text { Greek; Kannada, } \\
\text { Maithili, Punjabi, and } \\
\text { others }\end{array}$ \\
\hline Source & $\begin{array}{l}\text { Temporal } \\
\text { "from" }\end{array}$ & $\begin{array}{l}\text { Haspelmath 1997:66-68; Heine \& } \\
\text { Kuteva 2002:35, } 317\end{array}$ & $\begin{array}{l}\text { Romanian, Polish, } \\
\text { Croatian, Chinese, } \\
\text { Kannada, Tamil etc. }\end{array}$ \\
\hline Companion & $\begin{array}{l}\text { NP- } \\
\text { Coordination }\end{array}$ & $\begin{array}{l}\text { Lord 1993:47ff; Michaelis \& Rosalie } \\
\text { 2000:90; Heine \& Kuteva 2002:80; } \\
\text { Heine 2003:595; Stassen 2003:785 }\end{array}$ & $\begin{array}{l}\text { Baka, Ewe, Dogon, } \\
\text { Hausa, Ga, Lingala, } \\
\text { Moré, Yagaria, } \\
\text { Turkish, French } \\
\text { Creoles, Chinese }\end{array}$ \\
\hline Companion & Possession & $\begin{array}{l}\text { Heine \& Kuteva 2002:88; Heine, } \\
\text { Claudi \& Hünnemeyer 1991:166; } \\
\text { Yamaguchi 2004:121; Stolz } \\
\text { 2001:340 }\end{array}$ & Swahili, Baka, Lingala \\
\hline Instrument & $\begin{array}{l}\text { Ergative } \\
\text { Agent }\end{array}$ & $\begin{array}{l}\text { Lehmann 1983:368; 1988:63; } \\
\text { 2002:73; Heine \& Kuteva 2002:180; } \\
\text { Palancar 2002:234 }\end{array}$ & $\begin{array}{l}\text { Hittite, Sanskrit, Avar, } \\
\text { Dyirbal, Mangarayi }\end{array}$ \\
\hline Instrument & $\begin{array}{l}\text { Passive } \\
\text { Agent }\end{array}$ & $\begin{array}{l}\text { Michaelis \& Rosalie 2000:90; Givón } \\
\text { 2001:263; Blake 2001:172; Luraghi } \\
\text { 2001b:395; Palancar 2002:161; } \\
\text { Lehmann 2002:98; Hopper \& } \\
\text { Traugott 2003:171; Yamaguchi } \\
\text { 2004:102, 112, 121, } 129\end{array}$ & $\begin{array}{l}\text { Russian, Czech, } \\
\text { Dravidian; CFs; Greek }\end{array}$ \\
\hline Location & Companion & $\begin{array}{l}\text { Luraghi 2001b:390; Yamaguchi } \\
\text { 2004:117; Endruschat 2007:63; } \\
\text { Heine (2008) }\end{array}$ & Greek, Carib; Romance \\
\hline $\begin{array}{l}\mathrm{NP}- \\
\text { coordination }\end{array}$ & $\begin{array}{l}\text { Clausal } \\
\text { Coordination }\end{array}$ & Frajzyngier 1996:29 & Chadic \\
\hline $\begin{array}{l}\text { Physical } \\
\text { Proximity }\end{array}$ & Companion & $\begin{array}{l}\text { Palancar 2002:125f; Endruschat } \\
2007: 58,61,63,84\end{array}$ & Romance \\
\hline Route & Instrument & $\begin{array}{l}\text { Luraghi 2001a:50; 2001b:390; } \\
\text { 2003:35; Palancar 2002:170, 183; } \\
\text { Yamaguchi 2004:129 }\end{array}$ & $\begin{array}{l}\text { Greek, Russian, } \\
\text { German, Polish etc. }\end{array}$ \\
\hline
\end{tabular}

Table 2: Uncontroversial sources and targets in the instrument-companion domain 


\subsection{Controversial directionalities}

With some of the connections listed above, the directionality is controversial. There are different ways in which this can be the case. First, and most saliently, converse directionalities of semantic extension have been posited. Secondly, in the case of some connections, it is not clear if the connection is direct or mediated by a third meaning/function. Thirdly, the directionalities of some connections may conflict with more general directionalities of meaning change posited in the general literature on grammaticalization and semantic change (e.g. Heine et al. 1991). We will begin by dealing with the first type of (apparent) contradiction, and then, more briefly, with the second type of contradiction. The third type, the violation of general rules of semantic change is dealt with in a separate section at the end of this paper (Section 8).

\section{From Instrument to Companion, from Companion to Instrument, or bidirectionality?}

With respect to the relationship between Instrument and Companion, the two opposite directionalities have been claimed to hold.

Numerous researchers have claimed in their work that Companion extends to Instrument but not vice versa. This hypothesis is supported in the following papers and books: Lehmann (1988:63); Heine, Claudi \& Hünnemeyer (1991:158, 166); Stroh (1998, 1999); Michaelis \& Rosalie (2000:90); Luraghi (2001a:50, 2001b:390); Stolz (2001:340); Heine \& Kuteva (2002:84); Palancar (2002:126); Lehmann (2002:99); Heine (2003:595); Yamaguchi (2004:121); Stolz, Stroh \& Urdze (2006:366, 369f); Endruschat (2007:59). The opposite relationship has been claimed in Givón (2001:263).

As evidence for a directionality of meaning extension from Companion to Instrument the following languages have been cited: Germanic (Heine, Claudi \& Hünnemeyer 1991:158); Latin and various Romance languages (Stroh 1998, 1999; Endruschat 2007:59) ${ }^{1}$; Greek (Luraghi 2001b:390; 2003:322); English; Estonian, Welsh (Stolz, Stroh \& Urdze 2006:366, 369). Heine, Claudi \& Hünnemeyer cite Priebsch \& Collinson's The German Language (1968 edition): "So-called instrumental was primarily a comitative or social case in Proto-Germanic".

In contrast, Givón (2001:263) provides no evidence. It is not clear how serious his claim, which is mentioned in passing, is to be taken. The evidence points overwhelmingly in the opposite direction. Additionally, the extension from Companion to Instrument fits the general directionality of grammaticalization and semantic change posited by Heine, Claudi \& Hünnemeyer $(1991: 156,158)$, namely from the marking of a human participant to the marking of an inanimate participant. Overall, we can therefore assume a unidirectional extension of Companion to Instrumental.

\section{From Location to Instrument, from Instrument to Location, or bidirectionality?}

In the following works, an extension from a locative to an instrumental function has been hypothesized: Blake (2001:173); Luraghi (2001a:50); Palancar (2002:126, 174, 239); Luraghi (2003:35f, 322, 88f); Grünthal (2003:139-141); Yamaguchi (2004:102, 106); Heine (2008). In

\footnotetext{
${ }^{1}$ Stroh, Stolz and Urdze (2006) support this claim, but they argue for a very complex history of this directionality of change in the Romance languages.
} 
contrast, Stolz (2001:340) has posited the opposite directionality.

Markers in the following languages and language groups have been cited as evidence for meaning extension from Location to Instrument: Pama-Nyungan, English (Blake 2001:173); Greek, Russian, and other Indoeuropean languages (Luraghi 2003:35f, 322, 88f); Finno-Ugric (Grünthal 2003:139-141). In contrast, no concrete marker in a specific language has been cited for the claim of opposite directionality.

In addition, general directionality of semantic change in grammaticalization supports the directionality from a locative to an instrumental function. Instrument is further advanced than Location on Heine, Claudi \& Hünnemeyer's (1991:159) "chain of increasing grammaticalization". Instrument belongs to "anthropocentric concepts", while Location belongs to "spatial concepts" (p. 160). We can assume here unidirectionality from Location to Instrument.

\section{From Instrument to Cause, from Cause to Instrument, or bidirectionality?}

Meaning extension from the marking of Instrument to the marking of Cause has been claimed by Palancar (2001:376; 2002:126, 166, 234); Luraghi (2003:37), and Yamaguchi (2004:102, 112f, 121, 129). The opposite direction has been claimed by Palancar $(2001: 377,381 ; 2002: 121,137$, 157). That is, Palancar, on conceptual grounds, sees bidirectionality.

As evidence for the directionality from Instrument to Cause, English, Spanish (Palancar 2001:376; Palancar 2002:165; Yamaguchi 2004:112) and Sanskrit (Luraghi 2003:37) have been cited. No specific language is cited for change in the opposite direction.

Heine, Claudi \& Hünnemeyer (1991:159f) see Cause further advanced than Instrument on the "chain of increasing grammaticalization", as the Instrument belongs to "anthropocentric concepts", and Cause belongs to "inanimate concepts" (p. 160). Overall, we can assume unidirectionality from Instrument to Cause.

\section{Direct or mediated relationship (A $>$ B or $\mathrm{A}>\mathrm{C}>\mathrm{B}$ ?)}

This subsection deals with five cases in which researchers have questioned whether a direct connection exists between meanings/functions $\mathrm{A} / \mathrm{B}$, or only an indirect relationship, mediated by a third meaning/function $\mathrm{C}$.

First, Palancar (2001, 2002) suggests that the path from Instrument to Passive Agent is not direct but always mediated by Cause. In contradiction to this, my synchronic database (Narrog \& Ito 2007) shows 16 out of 29 instrumental morphemes with a Passive Agent meaning and having no causal meaning. It is therefore very likely that the path from Instrument to Passive Agent is not obligatorily mediated by a Cause function.

The second problem is related, as it concerns the path from Companion to Passive Agent. Heine \& Kuteva (2002:80) suggest that: "It [the path from Comitative to Passive Agent] might involve an intermediate INSTRUMENT stage." This is indeed very likely. The connection from Companion to Passive Agent as such is rare. In my database of companion and instrumental markers in 200 languages, only 7 companion markers had a passive agent function. Only a single one of them (namely Hoava preposition $t a-$ ) had no instrumental function (this could be chance because in some cases intermediate functions disappear historically). Therefore, a direct extension from Companion to Passive Agent is rather unlikely.

The third question is whether there is a direct connection between Companion and Clausal Coordination or only one mediated by Nominal Coordination. Heine \& Kuteva (2002:83) 
comment that, "[w]e may be dealing with a more general evolution COMITATIVE > NP-AND > S-AND." In my synchronic database, not a single example of polyfunctionality between Companion and Clausal Coordination without Nominal Coordination could be found. Therefore, a direct extension from Companion to Clausal Coordination can be excluded.

\subsection{Overlooked connections}

Concerning three of the connections posited in the Narrog \& Ito (2007) map (Figure 4), no specific directionality has been posited in the literature. These are Companion and Co-participant, Instrument and Material, and Instrument and Duration. Nevertheless, I will hypothesize in all three cases that the minor function (Co-participant, Material, Duration) can be seen as an extension of the major function (Instrument, Companion). In fact, depending on the point of view, the Co-Participant and Material functions can be regarded as part of the vagueness of the two major functions that arise in specific contexts. Concerning the Duration function, this can be regarded as another extension from non-temporal to temporal meaning rather than vice versa, which would be a very rare and unlikely phenomenon.

\subsection{Resulting map}

Overall, in the case of the Companion-Instrumental area, it is possible to posit fairly solid hypotheses for all directionalities. If the directionalities are added to the synchronic map (none of the connections on the map in Figure 4 was removed), the map in Figure 5 is obtained.

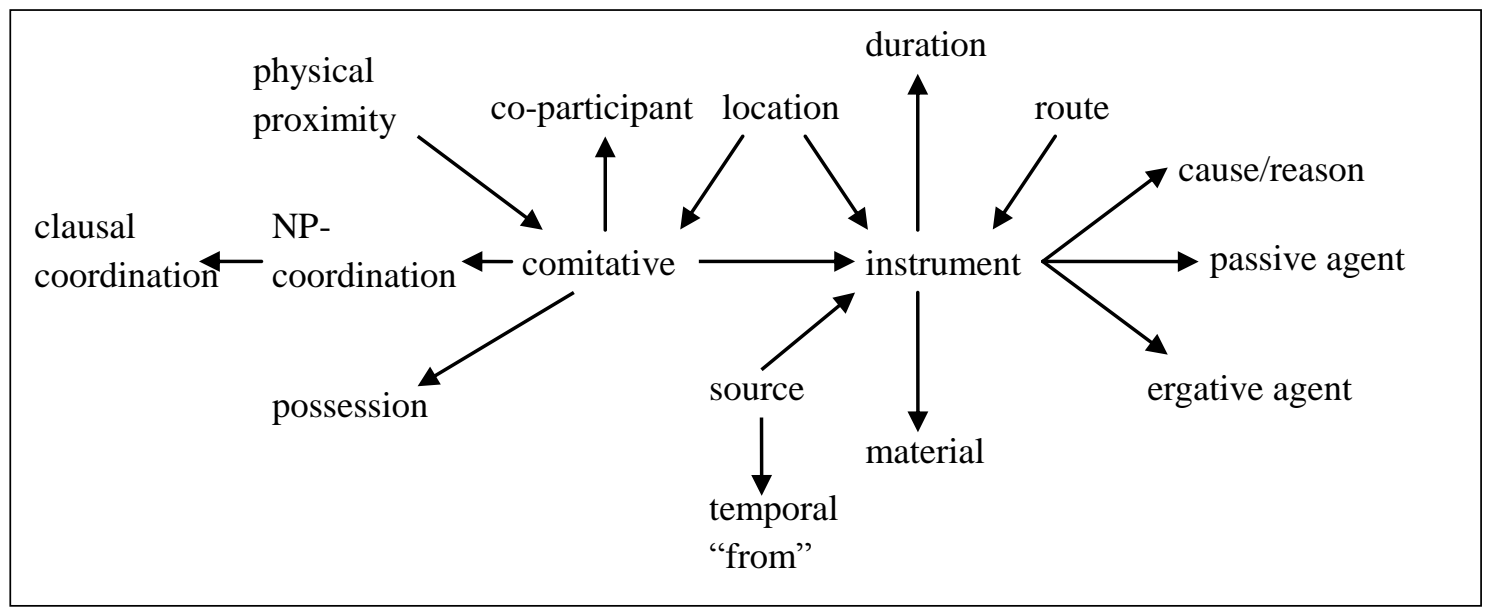

Figure 5: Semantic map of the instrumental domain with directionality of meaning extension

This map can be further extended with a number of connections that we have not observed in the synchronic data but which are posited in the diachronic and grammaticalization literature.

First, Michaelis \& Rosalie (2000:90) have suggested an extension from Companion to Recipient in French Creoles. Second, some researchers have noticed an extension from Companion to Manner (Heine \& Kuteva 2002:87; Yamaguchi 2004:121; German, Hausa, Ngbaka, Hungarian, Tamil as evidence) and from Instrument to Manner (Heine, Claudi \& Hünnemeyer 1991:166; Givón 2001:263; Luraghi 2001b:390; H\&K 2002:180; Yamaguchi 2004:102, 121; German, Basque, Ewe, Yoruba as evidence). These two relationships are 
somewhat controversial, however. Namely, concerning the relationship between Companion and Manner, Heine and Kuteva (2002:87) speculate that, "[t]his process probably does not lead straight from COMITATIVE to MANNER but appears to have INSTRUMENT as an intermediate stage [...]." My synchronic database (cf. Narrog \& Ito 2007) shows that 12 out of 42 companion morphemes with manner meaning have no instrumental meaning. Therefore, although there is certainly a mediated path from Companion to Manner via Instrument, it is quite likely that a direct connection exists as well.

Lastly, a putative relationship between Instrument, Companion, and Point of Time markers has been noted (Heine \& Kuteva 2002:89; Awtuw, German, Basque, Hausa, Ngbaka, Hungarian and Albanian as evidence). The authors remark, however, that "[c]onceivably, TEMPORAL markers are not derived straight from COMITATIVE markers but rather are part of a more extended pathway COMITATIVE > INSTRUMENT > TEMPORAL [...]" (Heine \& Kuteva (2002:90). In my synchronic database of companions, only 5 out of 27 companion-marking morphemes with a temporal (point in time) meaning have no additional instrumental meaning. Therefore, Heine \& Kuteva's (2002) suggestion is probably correct, but this case is less clear than the preceding ones.

A map that also includes these connections is presented in Figure 6. This map is visually less elegant than the preceding one, but presumably more comprehensive. The newly added connections are marked in green.

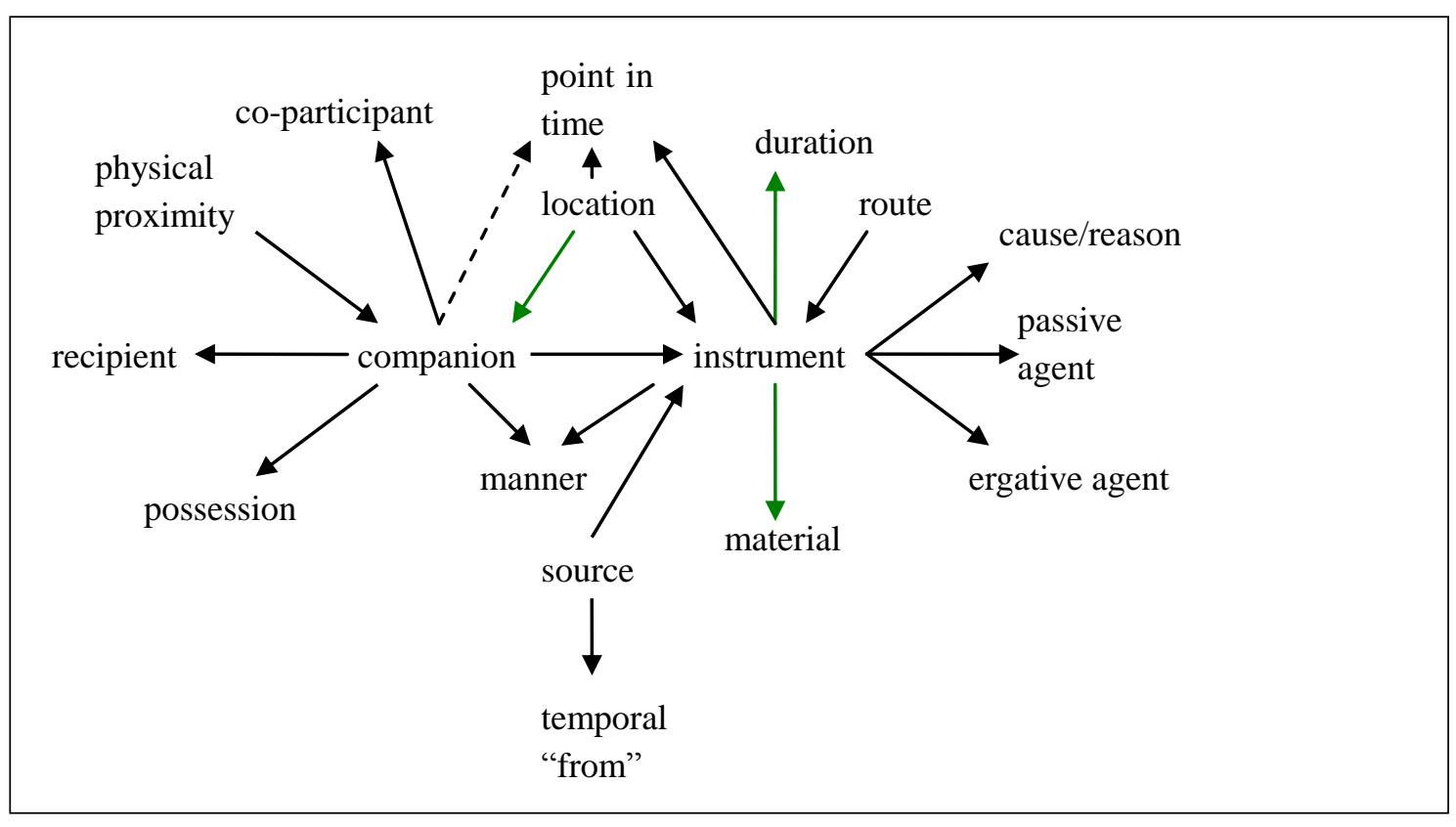

Figure 6: Revised diachronic map of the instrumental/comitative domain 


\section{The Source-Agent Domain}

\subsection{Synchronic data}

In the case of the Source-Agent domain, synchronic data from the 200-languages sample were collected and analyzed just as for the Instrument-Companion domain. On the basis of the analysis, the following connections could be hypothesized.

(1) Based on dependency of one meaning/function on another, with at least 5 morphemes for which both meanings are available: Anterior conjunction "after" - Source (dependency ratio 1.00); Temporal point of departure - Source (dependency ratio 1.00); Contents "about" - Source (0.95), Genitive/Partitive - Source (0.94); Goal - Source (0.93).

(2) "Unique" connections between two meanings (that is, a morpheme which only has exactly these two meanings/functions) in at least three morphemes: Temporal point of departure - Source (13); Goal - Source (4); Instrument - Ergative agent (4); Location - Source (3)

(3) "Unique" connections between two meanings in two languages (less strict condition): Passive Agent - Source; Passive Agent - Instrument; Passive Agent - Cause; Partitive/Genitive Source; Source - Route; Source - Goal; Possessor - Source.

On the basis of these hypothesized connections, the map in Figure 7 can be constructed:

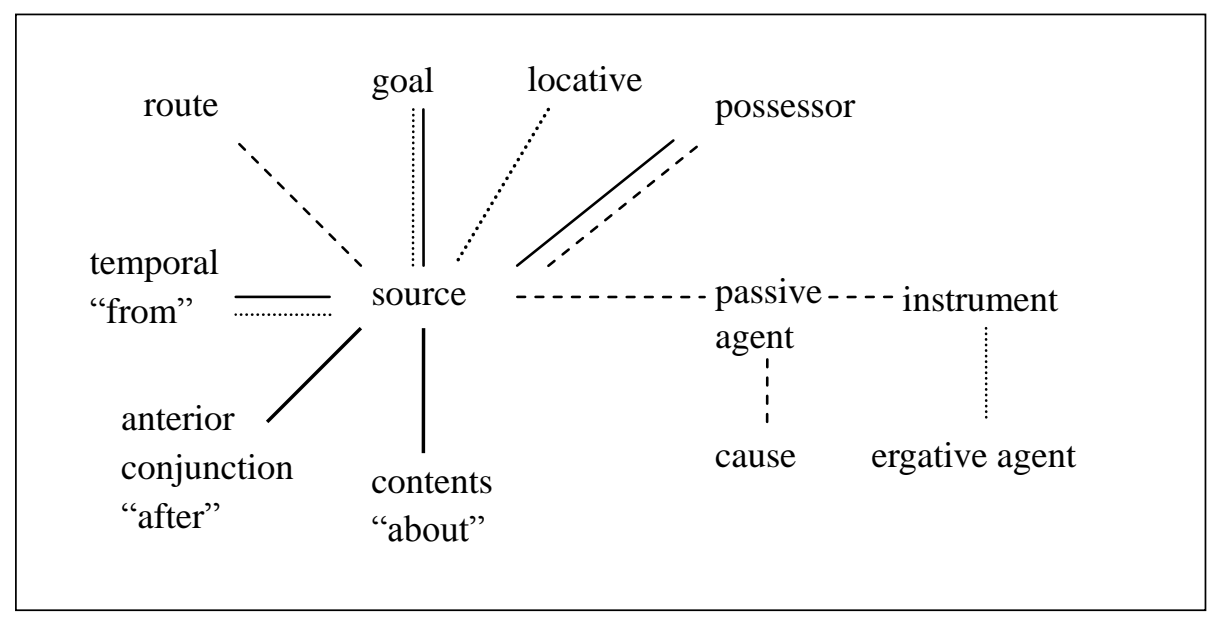

Figure 7: Map of the Agent-Source domain

One interesting fact is that this map shows no connection between Passive Agent and Ergative Agent, though this connection is obvious to linguists with a diachronic background. The reason is that this connection cannot be extracted with the help of the synchronic data and the methods employed here. The function of a marker is usually described as either passive, or, when the passive diachronically becomes an ergative, as ergative, but not as both simultaneously. The following subsections compensate for this shortcoming by introducing diachronic connections 
into the map.

\subsection{Uncontroversial directionalities}

Table 3 presents those directionalities in the Source-Agentive area which are not contested in the literature and which were not already listed in Table 2.

\begin{tabular}{|c|c|c|c|}
\hline Source & target & $\begin{array}{l}\text { literature supporting this } \\
\text { directionality }\end{array}$ & language examples cited \\
\hline Source & Cause & $\begin{array}{l}\text { Yamaguchi 2004:135; Luraghi } \\
\text { 2001a:50; Palancar 2001:381; } \\
\text { Palancar 2002:120, 157; } \\
\text { Creissels (2008) }\end{array}$ & $\begin{array}{l}\text { English, German, Greek, } \\
\text { Spanish }\end{array}$ \\
\hline Source & Causee & Palancar 2002:181 & Kannada, Maithili, Punjabi \\
\hline Source & $\begin{array}{l}\text { Tertium } \\
\text { Comparationis }\end{array}$ & $\begin{array}{l}\text { Heine \& Kuteva 2002:30, 317; } \\
\text { Yamaguchi 2004:135; } \\
\text { Creissels (2008) }\end{array}$ & $\begin{array}{l}\text { Latin, Bulgarian, Tibetan, } \\
\text { Turkish, Aranda }\end{array}$ \\
\hline Source & Ergative Agent & Palancar 2002:234 & Tauya, Dani, Athpare \\
\hline $\begin{array}{l}\text { Passive } \\
\text { Agent }\end{array}$ & Ergative Agent & $\begin{array}{l}\text { Givón 2001:263; Hopper \& } \\
\text { Traugott 2003:171; Lehmann } \\
\text { 2002:98; Palancar 2002:242; } \\
\text { Heine (2008) }\end{array}$ & Tibetan, Dyirbal, Avar, Tiriyo \\
\hline Dative & Passive Agent & $\begin{array}{l}\text { Lehmann 2002:98; Givón } \\
\text { 2001:263; Palancar 2002:192, } \\
197\end{array}$ & $\begin{array}{l}\text { Indo-Iranian languages; } \\
\text { Eskimo-Alëut languages; } \\
\text { Mansi, Nigerian Arabic, } \\
\text { Kayardild }\end{array}$ \\
\hline $\begin{array}{l}\text { Ergative } \\
\text { agent }\end{array}$ & $\begin{array}{l}\text { Nominative/ } \\
\text { Subject }\end{array}$ & $\begin{array}{l}\text { Givón 2001:263; Lehmann } \\
\text { 1988:63; Lehmann 2002:98; } \\
\text { Heine (2008) }\end{array}$ & Sherpa, Georgian, Mingrelian \\
\hline $\begin{array}{l}\text { Genitive/ } \\
\text { Partitive }\end{array}$ & Ergative Agent & $\begin{array}{l}\text { Lehmann 1988:63; Lehmann } \\
\text { 2002:98; Heine (2008) }\end{array}$ & Lak, Eskimo, Sherpa \\
\hline $\begin{array}{l}\text { Genitive/ } \\
\text { Partitive }\end{array}$ & Passive Agent & $\begin{array}{l}\text { Givón 2001:263; Blake } \\
\text { 2001:172 }\end{array}$ & Greek \\
\hline
\end{tabular}

Table 3: Uncontroversial sources and targets in the ablative-agentive domain

In violation of the procedure in this paper of assigning default semantic readings to case labels, in Table 3 this was not done with "Dative" in the extension from Dative to Passive Agent. The reason is that all authors positing the extension from a dative function to a Passive Agent label the function as "Dative" and not one as "Recipient". Furthermore, it is not clear at all if the extension from Dative to Passive agent can indeed by felicitously labeled as an extension from Recipient to Passive agent. It is entirely conceivable that "Dative" already needs to be 
generalized to a syntactic "third argument" marker or general oblique marker in order to be extended to Passive Agent marking. As an exception to the rule we will therefore use the morphosyntactic label "Dative" in the map.

\subsection{Controversial directionalities}

Only one connection with controversial directionality is found in this area. A directionality of meaning extension from Passive Agent to Cause has been posited by Luraghi (2003:327) and Yamaguchi $(2004: 135,121,129)$. The opposite directionality has been claimed by Michaelis \& Rosalie (2000:90) and Palancar (2001:374). As evidence, Luraghi (2003) cites Greek while Michaelis \& Rosalie (2000) cite the French Creoles. In Heine, Claudi \& Hünnemeyer's (1991:159) framework, the directionality from Passive Agent to Cause would be favored as an extension from a human to a non-human domain. Nevertheless, since evidence is available for both directionalities we posit bidirectionality at this point.

\subsection{Overlooked connections}

A number of connections which were found in the synchronic data have been overlooked in the diachronic/grammaticalization literature (unless the oversight is due to having overlooked the relevant literature). These are the connections Goal-Source, Location-Source, Route-Source, Anterior Conjunction-Source, and Contents-Source. In fact, Lehmann (1988:63) posits an extension from Ablative to Locative, and Rice \& Kabata (2007:486) posit the opposite direction but without providing concrete examples. It is difficult if not impossible to make any ad-hoc decision about the directionality between Goal-Source, Route-Source, and Location-Source. These are questions left for further research. With respect to the relationship between Source and Anterior conjunction and Contents, we may hypothesize, as in the case of Instrumental/Companion, that the minor functions (Temporal Anterior, Contents) are contextual extensions of the major function.

\subsection{Resulting map}

Figure 8 shows the map resulting from the directionalities hypothesized in the preceding subsections. They are marked in black. The connections for which no directionality could be posited (i.e. Source with other spatial functions), are marked in blue. Instrument and its surrounding connections, which were already specified in Figure 6, are left out so as not to overload the map. 


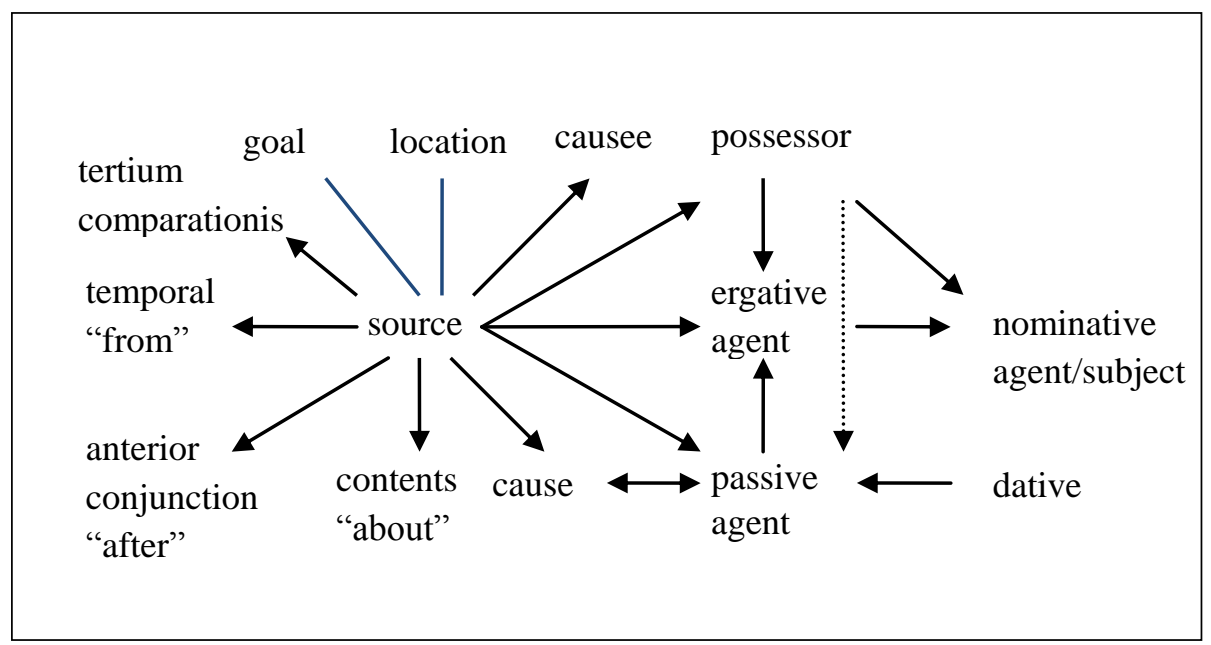

Figure 8: Agent-Source domain

\section{The Goal-Recipient Domain ${ }^{2}$}

The last semantic domain to be investigated in this study is the Goal-Recipient area. For this area, no synchronic data has been obtained and therefore the resulting map relies solely on diachronic hypotheses.

\subsection{Uncontroversial directionalities}

The directionalities in meaning extension in this area which are listed in Table 4 have not raised any controversy.

\footnotetext{
${ }^{2}$ Morphemes that were labeled as "Dative" in the literature were interpreted as Recipient markers for this study. That is, it was assumed that dative markers have at least a recipient function. Of course, they may have an Experiencer function, etc. as well.
} 


\begin{tabular}{|c|c|c|c|}
\hline source & target & $\begin{array}{l}\text { literature supporting this } \\
\text { directionality }\end{array}$ & language examples cited \\
\hline Goal & Beneficiary & $\begin{array}{l}\text { Heine, Claudi \& Hünnemeyer } \\
\text { 1991:155; Heine 2003:595; } \\
\text { Yamaguchi 2004:80; Luraghi } \\
\text { 2003:325 }\end{array}$ & English, Ik, Greek \\
\hline Goal & Recipient & $\begin{array}{l}\text { Haspelmath 2003:234; Michaelis } \\
\text { \& Rosalie 2000:90; Luraghi } \\
\text { 2003:39, Rice \& Kabata 2007:483 }\end{array}$ & $\begin{array}{l}\text { English, French, French } \\
\text { Creoles }\end{array}$ \\
\hline Goal & Purpose & $\begin{array}{l}\text { Heine \& Kuteva 2002:39, 317; } \\
\text { Haspelmath 2003:234; Heine } \\
\text { 2003:595; Luraghi 2001a:50; Rice } \\
\text { \& Kabata 2007:483; Creissels } \\
\text { (2008) }\end{array}$ & $\begin{array}{l}\text { Imonda, Albanian, Lezgian, } \\
\text { Basque }\end{array}$ \\
\hline Recipient & Patient & $\begin{array}{l}\text { Givón 2001:263; Heine 2003:595; } \\
\text { Hopper \& Traugott 2003:167; } \\
\text { Lehmann 1988:63; Lehmann } \\
\text { 2002:99; Heine \& Kuteva } \\
\text { 2002:103 }\end{array}$ & $\begin{array}{l}\text { Dolakha Newari, English, } \\
\text { Spanish, Burmese, Persian }\end{array}$ \\
\hline Benefactive & Purpose & $\begin{array}{l}\text { Heine, Claudi \& Hünnemeyer } \\
\text { 1991:155; Heine \& Kuteva } \\
\text { 2002:55, Yamaguchi 2004:85, } 78\end{array}$ & $\begin{array}{l}\text { Bulgarian, English, Yaqui, } \\
\text { Easter Island, Baka, Newari, } \\
\text { Maltese, Slave and others }\end{array}$ \\
\hline Recipient & Experiencer & Haspelmath 2003:234 & (no examples) \\
\hline Recipient & Possessor & Haspelmath 2003:234 & $\begin{array}{l}\text { Armenian, Swedish, Diyari, } \\
\text { Baka, Aranda, French, } \\
\text { German etc. }\end{array}$ \\
\hline
\end{tabular}

Table 4: Uncontroversial sources and targets in the dative-allative domain

\subsection{Controversial directionalities}

In this area, a good number of controversial directionalities of meaning extension can be found. They will be discussed in the following five subsections.

From Beneficiary to Recipient, from Recipient to Beneficiary, or bidirectionality?

A meaning extension from Beneficiary to Recipient has been claimed by Lehmann (1983:368; 2002:99), Heine, Claudi \& Hünnemeyer (1991:151, 155), Michaelis \& Rosalie (2000:90); Givón (2001:263), Heine \& Kuteva (2002:54), and Haspelmath (2003:234). The opposite directionality has been claimed by Givón (2001:263), Luraghi (2001a:50), Rice \& Kabata 2007:483 and Kittilä (2005:85). 
One concrete indicator (language) has been cited for the extension from Beneficiary to Recipient, namely Brazilian Portuguese (Lehmann 2002:99), while no concrete evidence besides internal reconstruction has been cited for the opposite direction. With respect to general directionality in semantic change, Heine, Claudi \& Hünnemeyer (1991:159) hypothesize that Dative/Recipient is further advanced on the "chain of increasing grammaticalization" than the Beneficiary. The reason is that the latter refers to a human participant while the former only involves some "human instigator" (i.e., does not necessarily mark a human participant itself). We tentatively follow this hypothesis here.

\section{From Location to Goal, from Goal to Location, or bidirectionality?}

Heine, Claudi \& Hünnemeyer (1991:155), Luraghi (2001a:50), and Rice \& Kabata (2007:483) have claimed meaning extension from Goal to Location while Luraghi (2001a:50) and Palancar (2002:190) have claimed the opposite direction; i.e. Luraghi (2001a) claims bidirectionality. However, no diachronic evidence has been brought forward for either directionality.

With respect to general directionalities of semantic change, Heine, Claudi \& Hünnemeyer (1991:155) claim that the extension from Goal to Location is part of a conceptual extension leading from a more concrete function to more abstract functions. In a similar vein, Langacker $(1990,1998)$ presents locative (stative) use of dynamic motion expressions (e. g. across the table, over the hill etc.) as instances of subjectification. Based on these conceptual considerations, we tentatively assume directionality from Goal to Location.

\section{From Purpose to Cause, from Cause to Purpose, or bidirectionality?}

Meaning extension from Purpose to Cause has been claimed by Heine, Claudi \& Hünnemeyer (1991:151), Luraghi (2001a:46-50; 2003:326), Heine \& Kuteva (2002:246); Heine (2003:595), and Yamaguchi (2004:80). The opposite directionality has been claimed by Luraghi (2001:46-50), i.e., this author basically claims bidirectionality. Evidence presented by Luraghi (2001a:46) for the extension from Purpose to Cause is the development of the English preposition for. The same directionality can be found for Japanese tame (cf. Nihon Kokugo Daijiten vol. 8:1131). The example given for the opposite directionality, namely Spanish para $(<$ por $+a)$ (Luraghi (2001a:46) is highly questionable because it does not reflect the semantic development of one morpheme but of the amalgamation of two morphemes. The general directionality of semantic change favors change from Purpose to Cause because "PURPOSE [...] normally presupposes some human agent and activity, whereas CAUSE does not" (Heine, Claudi \& Hünnemeyer (1991:157)).

\section{From Beneficiary to Purpose, from Purpose to Beneficiary, or bidirectionality?}

Meaning extension from Beneficiary to Purpose has been claimed by Heine, Claudi \& Hünnemeyer (1991:151), Heine \& Kuteva (2002:55f), Yamaguchi (2004:80), and Blake (2004:1087), while the opposite direction has been claimed by Luraghi (2003:41). As evidence for a Beneficiary > Purpose extension, Heine \& Kuteva (2002:56) have cited the English preposition for, and Blake (2004:1087) has cited Australian languages with dative markers for nominal constituents that extend to Purpose with verbal/clausal constituents. No evidence has been presented for the opposite direction. 
With respect to the general directionality of semantic change and grammaticalization, Heine, Claudi \& Hünnemeyer (1991:157) state that "[b]oth [Beneficiary and Purpose] share some feature of goal orientation [...], but they differ from each other essentially in that BENEFACTIVE typically presupposes a human participant [...], whereas PURPOSE requires a nonhuman participant." Apart from this conceptual consideration, the better evidence is on the Beneficiary > Purpose side, so we assume here that change goes in this direction.

\section{Others}

Four further directionalities have been proposed in the literature which I consider as doubtful. First, Palancar (2002:137) has suggested an extension from Beneficiary to Reason/Cause, but it would seem more plausible to me to have Purpose, which is closely related to both, intervening between these two functions. Furthermore, Lehmann (2002:73) and Palancar (2002:126) both suggest an extension from specific locative cases (superessive in Bulgarian and adessive in Hunzib) to Dative. There are two questions in need of clarification with respect to these directionalities. Firstly, while Recipient is doubtlessly the core dative function, in the case of a shift from a stative locative function to Dative, the bridging function might not be Recipient but rather Possessor or Experiencer. Secondly, as Luraghi (2003:51) claims for Indo-European, allative functions, i.e. Goal, might be involved, either intermediately between a stative locative and the Recipient function, or preceding the stative locative function but directly connecting to the Recipient functions. Likewise, a presumptive extension from Goal to Patient (cf. Heine \& Kuteva 2002:38, 317; Blake 2001:171; examples from Imonda and Spanish) always seems to involve Recipient as well. ${ }^{3}$ Recipient might therefore be an obligatorily intervening function. Furthermore, the possible extension from Goal to Experiencer has only been mentioned once (Heine \& Kuteva 2002:38) and for one language (Lezgian). Caution is warranted here although this extension seems intuitively plausible.

\subsection{Resulting map}

The connections and directionalities as hypothesized in the preceding subsections can be integrated as in the map in Figure 9. Experiencer is not included because the evidence for directionalities involving this function was rather weak. Those directionalities which are especially tentative are marked by a dashed line.

${ }^{3}$ I wish to thank Andrej Malchukov for pointing this out to me. 


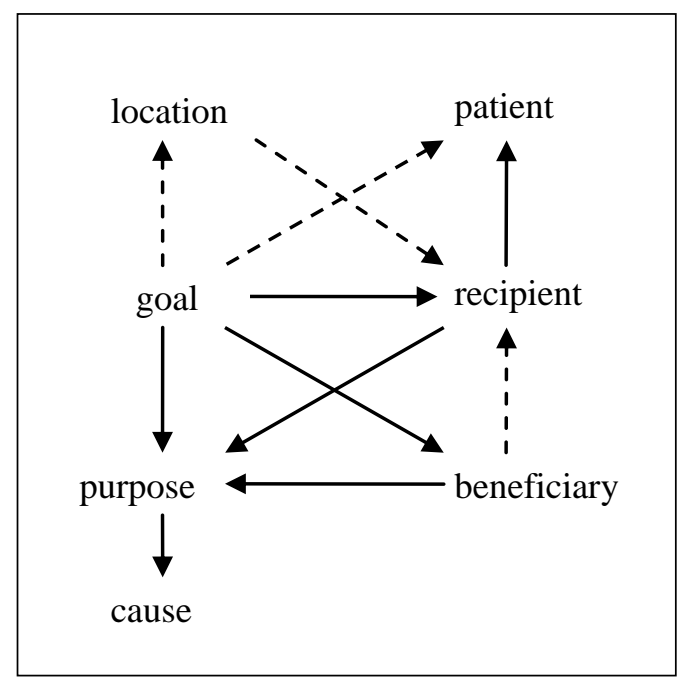

Figure 9: Map of the Goal- Recipient domain

\section{Conflicts of the Observed Directionalities in Meaning Extension with Conceptual Considerations}

The last topic to be discussed in this paper concerns conflicts between directionalities actually observed and conceptually motivated theoretical claims about the directionality of semantic change in grammaticalization. This concerns specifically the "chain of increasing grammaticalization of case functions" posited by Heine, Claudi \& Hünnemeyer (1991). This chain is represented in Figure 10.

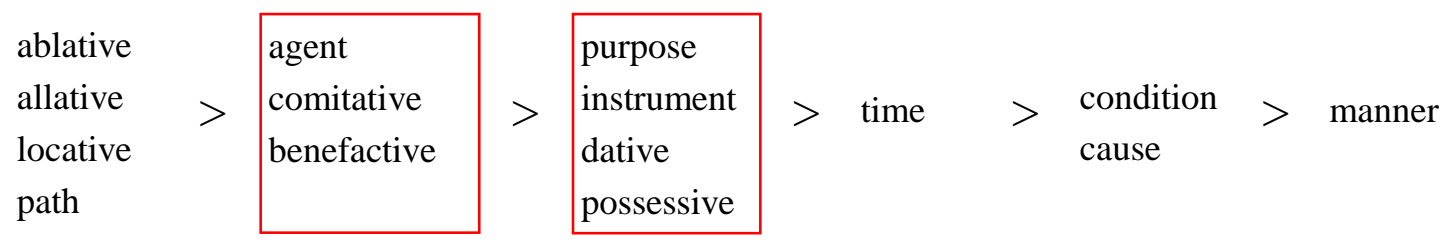

Figure 10. Chain of increasing grammaticalization of case functions (Heine et al. 1991:159)

Conflicts with actual directions of change can be observed in exactly one part of the chain, namely between the second and the third block (column), which are consequently encircled. This concerns change from (potentially also inanimate) "participants in human activity" (third column) to a "human participant" (second column), especially actors.

Concrete counterexamples are acquisition of the Passive Agent function by dative markers, and Ergative and Passive Agent functions by instrumental markers. None of these changes is particularly controversial, and thus they are fairly solid counterexamples to the putative general directionalities. One can imagine even more counterexamples, e.g. from Possessive to Agent (for example, change of Japanese no from Possessive to Nominative/Agentive marker). The only possible conclusion for this dilemma that I can imagine here is to dissolve these two groupings and rearrange them according to changes which have actually been observed. This is a task which requires more data than that presented here, and I will therefore make no attempt to solve it in this paper. 


\section{Summary}

I have argued in the first section of this paper that the inclusion of diachronic information (directionality in meaning extension) gives unique value to non-statistical semantic maps. The following sections were a demonstration of how diachronic information can be included in semantic maps of case functions. Three areas of case functions, Companion-Instrument, Source-Agent, and Goal-Recipient were investigated. In the case of the Goal-Recipient area, the map was even constructed solely on the basis of this type of information.

Surprisingly, in the case of most connections a clear directionality between two connected meanings/functions could be hypothesized. It would be naïve to assume, however, that they can always be backed up by solid historical evidence. Some hypotheses about directionality are based on "internal reconstruction", i.e., ultimately on researchers' intuitions or specific theoretical premises. On the condition of these limitations, the construction of diachronic semantic maps is an area of research that certainly merits further exploration.

\section{References}

Anderson, Lloyd B. 1982. The "perfect" as a universal and as a language specific category. Tense - Aspect: Between Semantics and Pragmatics, ed. by Paul J. Hopper, 227-264. Amsterdam: Benjamins.

-----. 1986. Evidentials, paths of change, and mental maps: typologically regular asymmetries. Evidentiality: The Linguistic Coding of Epistemology, ed. by Wallace Chafe and Marianne Mithun, 273-312. Norwood: Ablex.

Blake, Barry J. 2001. Case. Second edition. Cambridge: Cambridge University Press.

-----. 2004. Case. Morphology. An International Handbook on Inflection and Word-Formation, vol. 2, ed. by Geert Booij et al., 1073-1090. Berlin: Mouton de Gruyter.

Creissels, Denis. 2008. Spatial cases. The Oxford Handbook of Case, ed. by Andrej Malchukov and Andrew Spencer. Oxford: Oxford University Press.

Croft, William. 1991. Syntactic Categories and Grammatical Relations. Chicago: Chicago University Press.

-----. 2001. Radical Construction Grammar. Syntactic Theory in Typological Perspective. Oxford: Oxford University Press.

Croft, William and Keith T. Poole. 2008. Inferring universals from grammatical variation: multidimensional scaling for typological analysis. Theoretical Linguistics 34/1.1-37.

Endruschat, Annette. 2007. Durch 'mit' eingeleitete präpositionale Objekte in den romanischen Sprachen. Bochum: Brockmeyer.

Frajzyngier, Zygmunt. 1996. Grammaticalization of the Complex Sentence. A Case Study in Chadic. Amsterdam: Benjamins.

Givón, Talmy. 2001. Syntax. Volume 1. Second edition. Amsterdam: Benjamins.

Grünthal, Riho. 2003. Finnic Adpositions and Cases in Change. Helsinki: Societé Finno-ougrienne.

Haspelmath, Martin. 1997. From Space to Time. Temporal Adverbs in the World's Languages. München: LINCOM.

-----. 1999. Why is grammaticalization irreversible? Linguistics 37.1043-1068. 
----- 2003. The geometry of grammatical meaning: semantic maps and cross-linguistic comparison. The new psychology of language, vol. 2, ed. by Michael Tomasello, 211-43. New York: Erlbaum.

Heine, Bernd. 2003. Grammaticalization. The Handbook of Historical Linguistics, ed. by Brian D. Joseph and Richard D. Janda, 575-601. Oxford: Blackwell.

----- 2008. Grammaticalization of cases. The Handbook of Case, ed. by Andrej Malchukov and Andrew Spencer. Oxford: Oxford University Press.

Heine, Bernd, Ulrike Claudi and Friederike Hünnemeyer. 1991. Grammaticalization: A Conceptual Framework. Chicago: Chicago University Press.

Heine, Bernd and Tania Kuteva. 2002. World Lexicon of Grammaticalization. Cambridge: Cambridge University Press.

Hopper, Paul and Elizabeth Traugott. 2003. Grammaticalization. Second edition. Cambridge: Cambridge University Press.

Kittilä, Seppo. 2005. Recipient-prominence vs. beneficiary-prominence. Linguistic Typology 9.269-297.

Langacker, Ronald W. 1990. Subjectification. Cognitive Linguistics 1/1.5-38.

----- 1998. On subjectification and grammaticalization. Discourse and Cognition: Bridging the Gap, ed. by Jean-Pierre Koenig, 71-89. Stanford: CSLI.

Lehmann, Christian. 1983. Rektion und syntaktische Relationen. Folia Linguistica 17.339-378.

----. 1988. On the function of agreement. Agreement in Natural Language. Approaches, Theories, Descriptions, ed. by Michael Barlow and Charles A. Ferguson, 55-65. Stanford: CSLI.

----- 2002. Thoughts on Grammaticalization. Second, revised edition. Erfurt: Seminar für Sprachwissenschaft der Universität Erfurt. (Arbeitspapiere des Seminars für Sprachwissenschaft der Universität Erfurt 9).

Lord, Carol. 1993. Historical Change in Serial Verb Constructions. Amsterdam: Benjamins.

Luraghi, Silvia. 2001a. Syncretism and the classification of semantic roles. Sprachtypologie und Universalienforschung 54/1.35-51.

----. 2001b. Some remarks on Instrument, Comitative, and Agent in Indo-European. Sprachtypologie und Universalienforschung 54/4.385-401.

----. 2003. On the Meaning of Prepositions and Cases. The Expression of Semantic Roles in Ancient Greek. Amsterdam: Benjamins.

Malchukov, Andrej. 2004. Towards a Semantic Typology of Adversative and Contrast Marking. Journal of Semantics 21/2.177-198.

Malchukov, Andrej and Heiko Narrog. 2008. Case polysemy and semantic maps. The Oxford Handbook of Case, ed. by Andrej Malchukov and Andrew Spencer. Oxford: Oxford University Press.

Michaelis, Susanne and Marcel Rosalie. 2000. Polysémie et cartes sémantiques: le relateur (av)ek en créole Seychellois. Études Créoles 23/2.79-100.

Narrog, Heiko and Shinya Ito. 2007. Reconstructing semantic maps. The Comitative-Instrumental area. Sprachtypologie und Universalienforschung 60/4.273-292.

Narrog, Heiko. 2008. Varieties of Instrumental. The Oxford Handbook of Case, ed. by Andrej Malchukov and Andrew Spencer. Oxford: Oxford University Press.

Nihon Kokugo Daijiten [Great Dictionary of the Japanese Language]. Second edition. 2001-2003. Edited by Nihon Kokugo Daijiten Dainihan Henshū Iinkai and Shōgakkan Kokugo Jiten Henshūbu. Tōkyō: Shōgakkan.

Palancar, Enrique L. 2001. Emergent markers: The relation of instruments, causes, and agents in 
grammatical constructions. Sprachtypologie und Universalienforschung 54/4.365-384.

-----. 2002. The Origin of Agent Markers. Berlin: Akademie. (Studia Typologica 5).

Rice, Sally and Kaori Kabata. 2007. Crosslinguistic grammaticalization patterns of the allative. Linguistic Typology 11.451-514.

Stassen, Leon 2003. Noun phrase conjunction. The coordinative and the comitative strategy. Noun Phrase Structure in the Languages of Europe, ed. by Frans Plank, 761-817. Berlin: Mouton de Gruyter.

Stolz, Thomas, Cornelia Stroh and Aina Urdze. 2006. On Comitatives and Related Categories. A Typological Study with Special Focus on the Languages of Europe. Berlin: Mouton de Gruyter.

Stolz, Thomas. 1994. Grammatikalisierung und Metaphorisierung. Sprachdynamik. Auf dem Weg zu einer Typologie des sprachlichen Wandels, Band 2, ed. by Benedikt Jeßing. Bochum: Brockmeyer.

-----. 2001. To be with $\mathrm{X}$ is to have $\mathrm{X}$ : comitatives, instrumentals, locative and predicative possession. Linguistics 39/2.321-350.

Stroh, Cornelia. 1998. Die Geschichte der Mit-Relationen im Französischen: Komitativ-Instrumental-Synkretismus mit Hindernissen. Sprachtypologie und Universalienforschung 51/2.131-156.

-----. 1999. Mit-Relationen in der Romania: Ein klarer Fall? Sprachtypologie und Universalienforschung 52/2.183-195.

Traugott, Elizabeth Closs and Richard B. Dasher. 2002. Regularity in Semantic Change. Cambridge: Cambridge University Press.

van der Auwera, Johan and Plungian, Vladimir A. 1998. Modality's semantic map. Linguistic Typology 2/1.125-139.

Yamaguchi, Kazuyuki. 2004. A Typological, Historical, and Functional Study of Adpositions in the Languages of the World. PhD thesis, University of New Mexico.

Author's contact information:

Heiko Narrog

Graduate School of Information Sciences

Tohoku University

Kawauchi 41

Aoba-ku

Sendai-shi, 980-8576

Japan

narrog@gmail.com 